\title{
“TELL ME WHAT IT FEELS LIKE”: ON THE VERBAL INTERFACE OF THE PHENOMENAL
}

\author{
SERGEI KUZEEV \\ Eötvös Loránd University of Budapest, Budapest, Hungary
}

KUZEEV, Sergei: "Tell me what it feels like": On the verbal interface of the phenomenal. Jazykovedný časopis (Journal of Linguistics), 2021, Vol. 72, No 3, pp. 723 - 738.

\begin{abstract}
Despite the several decades of intense scrutiny, the problem of the "explanatory gap" remains one of the most widely debated topics in today's philosophy of mind. This paper argues that, if re-iterated as the relative ineffability of phenomenal properties of sensory experiences (qualia), it can become an object of linguistic treatment to a sensible effect. The paper proceeds from discussing the general ineffability of sensory experiences to a brief overview of phenomenal mental states. The strong ineffability thesis is then relativized by positing that the mental contents in question can be communicated indirectly through phenomenal judgments, or "phenomemes", i.e. discursive units that involve reference to the speaker's qualia. In the concluding section, the paper suggests that phenomemes constitute a narrative dimension of their own and highlights the potential of further research on the subject for the pragmatics of communication, cognitive stylistics, and other areas of the language-related scholarship.
\end{abstract}

Key words: phenomemes, phenomenology, phenomenal concepts, language and qualia, cognitive poetics, narrativity

\section{INTRODUCTION}

It has been observed many a time that some of our mental contents - specifically, those related to sensory ${ }^{1}$ experiences - are notoriously resistant to verbalization, and that, even when communication does occur, there remains a felt gap between what is meant and what is said. For those of the positivistic mindset, there is nothing mysterious about this unsayability, since to them it only signals a lack of linguistic competence; others, however, do not discard the problem so easily and assume that it owes to the incongruence between how the sensual domain and public language work. But what rarely receives systematic attention is the actual linguistic interface of the said gap, that is, the specific mechanisms of overcoming the ineffability of those sensory experiences that we typically find hard to verbalize.

The paper makes an attempt at re-articulating this problem as the relative ineffability of phenomenal mental contents, or qualia, i.e. of the intrinsically private non-propositional knowledge that we acquire when undergoing sensory experiences.

${ }^{1}$ Hereinafter used to refer, collectively, to all sorts of emotional, interoceptive, and bodily experiences. 
I begin with a general outline of ineffability of sensory experiences and proceed to a brief discussion of the subjectivity of qualia and its language-related effects. I then suggest that qualia are only ineffable in the weak sense - insofar as they need to be addressed directly. Based on evidence from the literary discourse, which is the principle realm of phenomenal contents organized as coherent text, I claim that we typically verbalize our phenomenology via relational descriptions which work, along the broad lines, similarly to resemblance metaphors. I dub those discursive units that refer to speaker's qualia and that are loosely based on the analytical notion of phenomenal judgments as phenomemes.

The essay concludes with a brief examination of phenomemes as a narrative technique that facilitates a more intimate engagement of readers with fictional texts and puts forth "mind reading" as a source of the interpretative insight. This research is motivated by the relative scarcity of attention to the relations between language and qualia (with the notable exception of, for instance: Berta, 2011; Carruthers, 1996; Zlatev, 2008), despite the manifest linguistic dimension of this problematic. The paper, thus, aims at devising a working model for discussing ineffability of phenomenal mental contents in the context of cognitive stylistics and discourse analysis.

\section{INEFFABILITY OF SENSORY EXPERIENCES}

There is a conviction, shared by much of the general public and scholars alike, that our public language is the most appropriate medium for articulate thought - that we appear to think with language ${ }^{2}$, one way or another, hence it should be virtually unfailing in its power to communicate ideas of whatever level of complexity. This sentiment is epitomized in Searle's principle of expressibility - "whatever can be meant can be said" - that has since become a foundational maxim for positivist thinking (1969, p. 19). Besides this aphoristic claim, it has an extended formulation, from which it follows that: 1) whatever has a meaning has an expression, 2) this expression is verbal in nature, and 3) each meaning can be conveyed directly; in other words, this principle asserts that there is effectively no gap between the thinkable and the sayable (1969, p. 19). Although we might have all practical reasons to believe so, there is another widespread intuition of equal force, which contradicts Searle's dictum and holds that the linguistic mode of expression must have its inherent constraints, for every now and then do we encounter those instances of verbal failure when putting some of our mental contents into words gets strangely problematic. ${ }^{3}$

One way to verify this intuition is to consider the relations between language and our sensual domain. On one level, we are endowed with the ability to introspect

${ }^{2}$ This is not to assert that all thinking is verbal. Rather, this is to assert, following Deacon (1997) and others, that language can be seen as the "scaffolding" for a wide range of cognitive processes.

${ }^{3}$ For an average adult native speaker of the language in question without such linguistic impairments as aphasia, alexithymia, etc. 
and meta-cognitively process the sensory experiences of our minds (normally, still in the presence of covert speech); but on another, this introspective process often reveals a gap between the impressionistic richness of what is accessible to our "mind's eye" and those routine linguistic structures that we use for day-to-day communication. When I am immersed into a piece of music, or when I contemplate a natural landscape, or simply enjoy a glass of wine on a quiet homely evening, I may discover, with some unease, that the vocabulary that we typically associate with such experiences - delight, amazement, tranquility, or comfort - does not do justice to how their sensory dimension is actually represented in my mind. Observing this imbalance engenders the insight that our affective states, at least to a degree, are somewhat beyond the linguistic horizon: each time we try to communicate them, we are beset with the sense of their ineffability, fragility against the machinery of language.

Fictional writing, where this kind of complication figures prominently, is another trusted source of evidence. Thus, the protagonist of Poe's short story Ms. Found in a Bottle remarks at some point: "A feeling, for which I have no name, has taken possession of my soul - a sensation which will admit of no analysis, to which the lessons of by-gone times are inadequate, and for which I fear the futurity itself will offer me no key" (2003, p. 57). Shakespeare offers a more succinct formula for this linguistic failure in King Lear, where the King's daughter Cordelia has to lament: "Unhappy that I am, I cannot heave my heart into my mouth", when asked to describe the way she feels for her father $(2009$, p. 7). Could this imply that language is not an adequate medium for the communication of our sensory experiences, since, as Susanne K. Langer once observed, it only "names certain vaguely and crudely conceived states, but fails miserably in any attempt to convey the ever-moving patterns, the ambivalence and intricacies of inner experience, the interplay of feelings with thoughts and impressions ..." (1942, p. 100)?

This Langer's diagnosis is presumably too radical to be taken at face value, even in view of the evidence supplied above, and to better understand the reasons for the failure that it so tellingly asserts, it needs to be reformulated in more adequate and balanced terms. On first approximation, we can restate the whole problem as simply the lack of names for those mental states that we find hard to verbalize, for "there is no set menu of discrete feeling kinds, no periodic table of the heart ... to specify cleanly and without residue" (Pilkington, 2001, p. 4). Worse still, this lack is logically persistent: there are evidently more possible affective states than even the most sophisticated medical and psychological taxonomies are able to tackle despite the presence of such nuanced terms as "anhedonia", "euthymia", "cachexia", and others in their lexicons.

That the lexical gaps in question are never entirely bridgeable, but are still continuously bridged by way of inventing (or borrowing) new words might be a trivial observation, which, however, continues to invite attention and spark 
debates. According to one commonsensical objection, this "neologizing" strategy simply inflates our vocabularies thus making them unusable for the general audience. This idea underlies the parodical online project of the Dictionary of Obscure Sorrows, whose authors invent mock terms with which to refer to those emotional circumstances that we might find uncannily familiar, but for which there are no words in actual dictionaries (at least, of the English language), for instance:

lachesism (noun): the desire to be struck by disaster - to survive a plane crash, to lose everything in a fire, to plunge over a waterfall - which would put a kink in the smooth arc of your life, and forge it into something hardened and flexible and sharp, not just a stiff prefabricated beam that barely covers the gap between one end of your life and the other (Koenig, 2021, p. 144).

vemödalen (noun): the frustration of photographing something amazing when thousands of identical photos already exist - the same sunset, the same waterfall, the same curve of a hip, the same closeup of an eye-which can turn a unique subject into something hollow and pulpy and cheap, like a massproduced piece of furniture you happen to have assembled yourself (Koenig, 2021, p. 217).

Thus, if we go back to our original complication, we will have to admit that the mere presence of lexical gaps is not the whole explanation: after all, what bothers both Poe's character and Shakespeare's Cordelia, and what Langer sees as the "miserable failure" of language, is not the lack of words per se, but, rather, the felt discrepancy between how our sensory domain and language system work on a more fundamental level. Perhaps, the best way to understand this discrepancy is to resort to the well-known dichotomy between the "analogue" and the "digital" modes of being. Since all our sensory inputs are, at root, the analogue phenomena determined by the laws of physics and chemistry, whereas language - at least as far as its essential design properties are concerned - is a "digital" code based on systematic forms of higher abstraction, the interaction between the two results in some kind of residue. Naturally, language is only able to "digitalize" the raw sensory data, but not to genuinely convey them in their original format:

"Our internal representations tend to be to a large extent simultaneous, unordered, and unorganized. When we transform them into a linguistic utterance, we of necessity have to break complex units into pieces and to string them together in a thoroughly ordered way - this is the raison d'etre of grammar - on the thread of speech. We thus externalize and make linear what was internal and non-linear beforehand" (Raible, 2003, p. 28).

${ }^{4}$ Of course, natural language cannot be said to be a purely "digital" phenomenon, as it also has certain "analogue" features. For a detailed discussion, see Love, 2007. 
The perceived ineffability of sensory states is thus due to their pre-verbal - if not altogether pre-conceptual ${ }^{5}$ - nature that is not easily compatible with the structural and semantic principles of public language.

The main difficulty with encoding sensory information in language is the peculiar organization of such analogue content in the form of infinite continuums of degrees. This is known as the ever-increasing "fineness of grain": while digital structures can be potentially reduced to some kind of a pixel - the minimal unit, beyond which things are no longer divisible - in real world the fineness of grain is potentially infinite. Thus, for instance, although color shades are a physical reality, their linguistic labelling is necessarily rough around the edges, for there are no stable boundaries between them, no actual criteria for a precise delineation. Even more so with our affective states: while everyday language does technically discern between anger and rage, sadness and anguish, excitement and happiness, these emotional experiences are still lived as continuums of transient feelings. At which point exactly anger becomes rage, sadness turns into anguish, and excitement grows into happiness depends entirely on the speaker's inclination to pick up a specific word to refer to her actual circumstance.

This incongruity between "raw feels" and linguistic categorization affects materially the way we communicate with each other, and many see it as the principle cause for the ineffability in question (Jakab, 2000; Musacchio, 2005). However, in order to identify the possible paths towards the relativization of this ineffability (beyond Searle's solution, which only postulates the absence of the gap as a methodological principle), this problem needs to be addressed from a more sophisticated perspective - the one afforded by the contemporary studies of consciousness, which will be the subject of the next section.

\section{SUBJECTIVITY OF QUALIA}

Despite their somewhat amorphous and (what seems to be) pre-verbal ${ }^{6}$ nature, those mental states in question that are open to introspection must nevertheless have properties which we can attend to and cognitively process. Such properties may be said to constitute their qualitative dimension, without which we would be "blind" to these states, the same way we are "blind" to those abstract phenomena for which we lack concepts - for instance, to the exact amount of objects before we learn to count. These qualities of lived experiences are often dubbed as their phenomenology $y^{7}$, or

\footnotetext{
${ }^{5}$ There is an ongoing debate about whether the mind's perceptual contents are conceptual or nonconceptual in nature. For an overview of the controversy, see Bermudez, 2009.

${ }^{6}$ Not all agree with this view. For instance, in the "multiple draft" model by Dennett (1991) and in the earlier version of the "higher-order thought" hypothesis by Carruthers (1996), introspective awareness is always mediated by language.

7 This has, of course, been the main focus of attention for the philosophical tradition of
} 
phenomenal character, but are now better known in philosophy of mind and cognitive sciences as qualia. This term was originally used in a more restricted sense - as consciously accessible non-representational features of sensory information (Lewis, 1991); today, however, qualia represent "introspectively accessible phenomenal aspects of our mental lives" (Tye, 2018). The very idea of qualia is based on the commonsensical observation that each and every sensory experience that we undergo has a subjective feel: put otherwise, it always feels a certain way to undergo them. When I look at the blue sky on a clear day, or sip cold beer after a long walk in summer, or listen to birds chattering in a grove, I get to know what it feels like to do and experience all those things without much of a cognitive effort: rather, this happens as a natural consequence of just my being conscious. Moreover, I can retrieve this kind of feelings from memory or re-create them through imagination, I can recognize them once they overwhelm me again, and I can surely tell one from another.

Qualia thus understood have been of little concern to the analytical tradition before 1974, when Thomas Nagel's seminal essay What Is It Like to Be a Bat? created a stir in philosophical circles. Nagel's principal achievement is an intuitively powerful reformulation of what it means to be phenomenally conscious (that is, to be aware of one's qualia): for an organism, to have conscious experiences means that there is something it is like to be that organism, or, in Nagel's own words, “... fundamentally an organism has conscious mental states if and only if there is something it is like to be that organism - something it is like for the organism" (1974, p. 441). This perspective has since become canonical, and many have concurred to the idea that our conscious sensory experiences are necessarily accompanied by the introspectively accessible feeling of their "what-it's-likeness". An equally important part of Nagel's reasoning is his conviction that there is no adequate vocabulary with which to describe the subjective character of sensory experiences, or, to be more precise, that there is no adequate vocabulary in which qualia could be communicated so as to be fully grasped by someone other than their actual bearer. This is due to the fact that qualia are beyond the reach of available concepts and represent "facts that do not consist in the truth of propositions expressible in a human language" (1974, p. 444). For most philosophers this still does not mean that our grasp of qualia is non-conceptual: that is, in order to be able to recognize, remember, or imagine them, we need to be equipped with a corresponding set of special "phenomenal" concepts, which "we exercise when (but not only when) we notice or become aware of the phenomenal character of our

\footnotetext{
phenomenology started by Husserl and continued by Merleau-Ponty, Scheler, Levinas, etc., while today's proponents of the phenomenological approach in cognitive sciences include Zahavi, Zlatev, Gallagher and many others. However, this paper is mostly concerned with the view of consciousness that is prevalent in today's analytical tradition rather than in the modern interpretations of the classical phenomenology.
} 
experiences and feelings via introspection" (Tye, 2003, p. 90). Today's "phenomenal concept strategy" is an umbrella term for an ever-increasing number of accounts ${ }^{8}$ for the lack of space here, I cannot do justice to the enormous body of work on the subject ${ }^{9}$, but will only mention that phenomenal concepts are most often construed as recognitional (Loar, 1990), indexical (Perry, 2001), or quotational (Papineau, 2007) entities of thought.

Despite the general acceptance of qualia as a useful conceptual tool for the understanding of consciousness, the thesis of their strong ineffability remains highly disputable and, as will be shown below, does not accommodate the existing empirical evidence. One line of criticism plays the pragmatic card, for it evokes the notion of "human endowment" to mitigate the whole problem: since many, if not most, of our sensory experiences are shared - and all of us are generally expected to know what it feels like, for instance, to be caught into a pouring rain, to fly in a shaky plane, or to have a bad toothache - verbal reports of sensory data turn out to be relatively unproblematic. ${ }^{10}$ This argument, however, looks past the possibility of deviant or uncommon experiences (being in the open space, taking exotic drugs, being pregnant from a male perspective, etc.), which evidently compromise the said endowment. Moreover, the problem of ineffability re-emerges when the subtlety of qualitative descriptions is of primary concern, as is the case with literary and poetic texts. ${ }^{11}$ According to Daniel Dennett - an ardent opponent of qualia's strong ineffability thesis ${ }^{12}$ - the conceptual isolation between perception and language notwithstanding, this gap can still be mitigated by purely verbal means, for "what it feels like to see Paris by moonlight in May can be adequately conveyed in a few thousand words (an empirical estimate based on the variable success of actual attempts by novelists)" (2005, p. 115). In what follows, I will build on this Dennett's proposal to determine the way we typically convey qualia in public language despite all the hurdles that such communication is assumed to face.

\section{PHENOMENAL JUDGMENTS, OR PHENOMEMES}

Naturally, the easiest way to follow up on Dennett's observation is to page through a few books, this time disregarding the instances of ineffability, but

\footnotetext{
${ }^{8}$ Since phenomenal concepts do not draw on general categories as "normal" concepts do, some suggest that there is no reason to term them as concepts after all (Ball, 2009).

${ }^{9}$ For a general overview of the phenomenal concept strategy, see Balog, 2009 and Sundström, 2001.

${ }^{10}$ And quite often involve, in casual speech, structures similar to "You (must) know this feeling when...".

${ }^{11}$ But, also, in some real-life settings, for instance, when reporting one's feelings and sensations to a therapist, etc.

12 And an opponent of qualia as such: see his essay Quining Qualia (1993) for a detailed argumentation of why the notion of qualia is philosophically incoherent.
} 
focusing on those descriptions of sensory experiences that reflect their phenomenal character. Formulated thus loosely, the task at hand might appear confusing; moreover, in a research like this, a valid methodology often comes in retrospect, so prior to clarifying criteria and identifying specific patterns, I will first share a few examples from fictional narratives, which hit the target, one way or another:

(1) More and more uncomfortable did Humbert feel. It was something quite special, that feeling: an oppressive, hideous constraint as if I were sitting with the small ghost of somebody I had just killed (Nabokov, 1991, p. 139).

(2) Some days I do appreciate things more, eggs, flowers, but then I decide I'm only having an attack of sentimentality, my brain going pastel Technicolor, like the beautiful-sunset greeting cards they used to make so many of in California (Atwood, 1986, p. 171).

(3) Turning away, I continued to drift downtown, with no very clear idea where I was going or why, and as I walked, I had the oddly appealing sensation that I was undoing myself, unwinding myself thread by thread, rags and tatters falling away from me in the very act of crossing Thirty-Second Street... (Tartt, 2014, p. 502).

To explain what these examples have in common and why I think that they are illustrative of how we communicate qualia in public language, I need to make a step back to Nagel's idea that all sensory experiences "feel like something" to us. The evasive "something" in this formula is utterly problematic, as it stands for the analogue mental contents that cannot be literally verbalized; but there seems to be a straightforward solution to this entanglement: to pick up another sensory experience to replace the ineffable "something". This will enable the speaker to convey the sense of qualia way more efficiently than through recognitional, indexical, or quotational models which the canonical accounts of the phenomenal concept strategy prescribe for the occasion (think of "I have this feeling" or "Here it goes again"). The main idea behind the substitution is, hence, to trigger in interlocutors the right sort of the imaginative insight rather than to genuinely say the unsayable; in parallel, this also creates the kind of verbal subtlety that is characteristic of the literary discourse as such.

Therefore, in all examples above, the speaker: 1) affirms the fact of undergoing a sensory experience (by naming it directly and/or by using the key verbs like "feel", "sense", etc.); 2) asserts that it has a felt quality, and 3) discloses this quality by assimilating the sensory experience in question with another experience. In (1), Humbert's discomfort of being with Lolita on a particular morning feels like being in the presence of the ghost of someone whom he has killed. In (2), Offred's depressive condition is likened to the loss of color vision: "going Technicolor". And in (3), Theodore's loneliness is described as the desire to "undo" or "unwind" 
himself. This is how the ineffability of qualia is most commonly relativized - through the use of figurative language, for though direct non-trivial descriptions of phenomenology might be inconceivable ${ }^{13}$, it can be more effectively communicated via "terms of associated external properties, or ... associated causal roles" (Chalmers, 1996, p. 20 - my italics).

In philosophy of mind, the utterances that are used to convey private mental contents are known as "phenomenal judgments", which can be understood, rather loosely, as "words, discussions, and texts about consciousness, subjective phenomena, and the mind-body problem" (Argonov, 2014, p. 53), or more restrictively, as statements containing explicit qualitative references. Such is the approach of David Chalmers, who discerns between the three types (or orders) of phenomenal judgments, exemplified as: "I have a throbbing pain now' ... 'LSD gives me bizarre color sensations' ... 'The problem of consciousness is utterly baffling'" (1996, p. 161). In this paradigm, phenomenal judgments may either assert the fact of undergoing a sensory experience (Type 1), or grasp its qualitative dimension (Type 2), or articulate generalizations on account of consciousness (Type 3). Clearly enough, I am here only concerned with Chalmers' Type 2 (or genuine) phenomenal judgments, since those of Type 1 only rely on the existing sensory vocabulary, and those of Type 3 do not elaborate on the phenomenal character of particular experiences.

The prototype of a phenomenal judgment is thus relatively simple: Experience $\mathbf{A}$ is (like) Experience B, which is akin to a resemblance metaphor, where the (real) Experience A is its target domain, or tenor, and the (imaginary) Experience B is its source domain, or vehicle. Each phenomenal judgment can be reduced to the said prototype, although the elaborate contexts of fictional writing may sophisticate the task. To showcase how this reduction may work, two more examples are shared below:

(4) To see Herald Square on television made me feel as if I were stranded millions of light-years from Earth and picking up signals from the early days of radio, announcer voices and audience applause from a vanished civilization (Tartt, 2013, p. 261).

(5) The moment of betrayal is the worst, the moment when you know beyond any doubt that you've been betrayed [...] It was like being in an elevator cut loose at the top. Falling, falling, and not knowing when you will hit (Atwood, 1986, p. 67).

It is easy to see that in (4), the Experience A from our formula is "seeing Herald Square (on TV)", while the imaginary Experience B is "being very far from

${ }^{13}$ Of course, qualia can also be communicated trivially via generic predicates, that is, by saying that things feel "good", "bad", "weird", etc., which is characteristic of casual spoken speech and is not of major interest. 
Earth in space and time". Along the same lines, in (5), the "feeling of betrayal" is metaphorically linked to "being inside a falling elevator".

To conclude this section, I suggest using a special term - "phenomemes"14 - for the phenomenal judgments in question in order to dissociate them from their philosophical counterparts (which have a broader coverage) and to establish them as a distinctive narrative unit. Of course, phenomemes are not the only possible carriers of phenomenal contents: the general organization of the text, the choice of words, and other techniques can undoubtedly serve this same purpose. What I hold is, however, that they appear to be the most organic and quintessential tool of "effing" the otherwise non-lexicalisable sensory experiences.

\section{TOWARDS PHENOMENAL DISCOURSE}

The study of qualia within linguistic settings might sound like a novel enterprise, however, there is a relatively long and vibrant history of research in the adjacent fields - for instance, of sensory vernaculars and the associated communicative strategies - as testified by the works of Wilma Bucci, Susanne K. Langer, Allan Paivio, and Klaus R. Scherer, to name but a few. The diversity and impact of these studies notwithstanding, they tend to share one common underlying principle, if not prejudice, present in Langer's diagnosis that I undertook to downplay: the overvaluation of verbal constraints on the communication of qualitative states. A typical project within this paradigm would build on the strong ineffability of sensory inputs and, sometimes, even call for construing "a language at the interface of science and poetry that may serve as a better approximation to qualia than is offered by declarative or propositional statements and yet amenable to formalization and quantification" (Zentner, 2012, p. 81) ${ }^{15}$.

Evidently, such studies are headed into a radically different direction from my proposal, that is, from positing that the relative ineffability of phenomenal mental contents does not diminish the ability of public language to communicate qualia. In fact, it is not unreasonable to suggest that the need to somehow cope with this ineffability by using language more creatively led to a significant upgrade in the capacities of human mind ever since linguistic competence had become a part of its repertoire. One legitimate objection that may arise in this connection is that although ineffability of qualia seems manageable in written texts, it might persist in the spoken register: as Bucci et al. reveal in their study, when asked to verbally elaborate on their emotional states, most speakers first undergo the stage of arousal, that is, of resorting to gestures and facial mimics combined with or followed shortly by reporting the

${ }^{14}$ Needless to say, here I follow the widely productive pattern, which figures in both established terms, like "phoneme" or "lexeme", and in more recent ones, like "pragmeme" or "sememe".

${ }^{15}$ The cited paper explores the possibility of creating a specialized vernacular more suited to communicate music-associated qualia. 
inability to fulfill the task immediately due to the lack of words (2016, p. 373). Perhaps, no clinical trials are needed to infer that grasping the right sort of vocabulary and reconceiving imaginatively of one's own feelings and sensations, let alone of qualitative states, is indeed a challenge that most speakers are unable to tackle on the spur of the moment. Moreover, the problem of verbalizing perceptual contents is mostly peripheral for colloquial speech, where, as mentioned above, reliance on the shared human endowment offers a working solution. As a consequence, all sensible analysis of phenomemes should proceed from written genres, where the stage of arousal and the associated verbal confusion are typically not part of the message. Phenomemes are indeed a staple feature of those many classical and contemporary works of fiction ${ }^{16}$ that gained an extensive readership, for instance, of the all-time favorite Handmaid's Tale by Margaret Atwood, quoted above more than once, where this manner of writing is especially prominent. Every now and then, Atwood masterfully depicts the dispiriting condition of her main protagonist by referencing the phenomenal dimension of her emotional and bodily experiences, for example:

(6) I sink down into my body as into a swamp, fenland, where only I know the footing. Treacherous ground, my own territory. I become the earth I set my ear against, for rumors of the future. [...] Each month I watch for blood, fearfully, for when it comes it means failure (1986, p. 63).

(7) You can wet the rim of a glass and run your finger around the rim and it will make a sound. This is what I feel like: this sound of glass. I feel like the word shatter (1986, p. 88).

The role of phenomemes thus understood goes far beyond framing immediate contexts: rather, they constitute a textual dimension of their own and evolve into a narrative technology of portraying subjective selves by immersing the audience into a web of fictional phenomenologies. As Elizabeth Camp notes in her speculations on Anna Karenina, L. Tolstoy's ambition throughout the many pages of his symphonic novel was to cause readers to identify with the main protagonist, which means "transforming [themselves] imaginatively, so that [they] become Anna Karenina... which involves imagining [themselves] being Anna Karenina, by imaginatively altering the content of who [they are]: endowing [themselves] with properties that Anna possesses which [they] lack..." (2009, p. 112). Although such identification can be achieved through various methods and writing techniques, I suggest that the use of phenomemes may be considered as a weapon of choice: there seems to be something intrinsic to this practice that enables the author to trigger a befitting emotional response in readers and to provide them with access to what is otherwise inaccessible: the mind of the Other.

\footnotetext{
${ }^{16}$ And even more so of poetry, although I leave it out of the present account.
} 
As mentioned in the previous sections, the principal philosophical problem of qualia, as already Gottlob Frege observed, is rooted in their ultimate reliance on their bearer: "no other person has my pain. Someone can have sympathy for me but still pain always belongs to me and his sympathy to him" (1956, p. 300). There is nothing logically incoherent in the possibility of "reading" the propositional contents of the minds of others, but grasping another person's experience in its phenomenological dimension remains logically impossible: all attempts to construe a thought experiment to this effect end in absurdity (Márton - Tözsér, 2016). What mitigates the solipsistic effects of qualia's privacy is our natural ability to adopt the first-person perspective. Even beyond that: the post-Gricean pragmatics of communication is predicated on the idea that "mind-reading", i.e. grasping and felicitously interpreting the speaker's meaning, lies at the core of mutual understanding as such (Watzlawick et al., 2014). This approach has grown into the paradigm of intersubjectivity of linguistic meanings that dates back to the famous Wittgenstein's fable of "beetles in the box" ${ }^{17}(2001, \S \S 244-271)$ and that is now used to analyze a wide range of discursive practices. But it is only in literature a laboratory of devising new and reiterating the existing tools of communicating the unsayable - where this intersubjective experience is of unmatched aesthetic and redemptive value. According to Margaret Freeman, each and every work of literary art is an embodiment of "poetic iconicity", that is, a complex of features that create in literary texts "sensations, emotions, and images that enable the mind to encounter them as phenomenally real" (2009, p. 177). Thus, the question of qualia should figure prominently across the field of literary studies, for:

“ 'Poetic concepts' and 'poetic thoughts' ... are difficult and relatively ineffable for a special reason: they encourage extensive encyclopaedic exploration and elaborate concept construction that involves the evocation of intense and subtle qualitative states. Such qualitative states cannot be described satisfactorily: they are non-lexicalisable. But insofar as they are effable, they evoke/arouse rather than simply characterise/describe an experience. Any attempt at a full discussion of poetic effects and poetic thoughts must discuss the evocation of qualitative states, and to this extent must reach out beyond pragmatic theorising" (Pilkington, 2001, p. 9).

Although this analysis is so far introductory and perforce sketchy, it aims at setting in motion a relatively novel program for the investigation of the "phenomenal discourse" and, most importantly, at further integrating the study of verbal art into the domain of cognitive science by demonstrating how intricately the former is linked with our understanding of the mind, both philosophical and pragmatic.

${ }^{17}$ Also known as the "private language argument", according to which linguistic meanings need to be shared within a community in order to serve their principal function. 


\section{CONCLUSION}

The problem of ineffable phenomenal contents is rooted firmly in the interdisciplinary problematics of the "explanatory gap" between physicalism and phenomenal consciousness. And while philosophers will, perhaps, never stop debating about the ontological consequences of the said gap, its epistemological effects can be assessed through the lens of the human language capacity and pragmatics of communication. To be more precise, it seems productive to view the discursive dimension of this problematic within the framework of cognitive poetics, which "[incorporates] the insights of cognitive science into literary studies" (Hart, 2001, p. 314). It is, primarily, fictional prose and poetry - not spoken speech that is often preferred in cognitive studies for being a more "organic" medium of verbal thought - which offer a wealth of evidence and help develop an understanding of how the qualitative dimension of sensory experiences, or "qualia", are conveyed in public language despite their alleged privacy and inexpressibility.

This paper started with the assertion that sensory experiences appear ineffable due to the incompatibility between the analogue nature of feeling and the "digital" structure of verbal expression. This ineffability is, however, only weak, or relative, for we are still able to convey the phenomenal contents of our minds via phenomenal judgments, or "phenomemes", which work along the lines of resemblance metaphors. As I briefly note in the closing section, phenomenal discourse constitutes a narrative technique, which might propel affective engagement of readers with texts and bring the paradigm of text interpretation as a mind-reading activity into focus. It is my hope that these preliminary findings might grow into a more substantial research and be a step forward in establishing the scope to which language affects or predetermines our cognitive performance.

\section{References}

ARGONOV, Viktor: Experimental Methods for Unraveling the Mind-Body Problem: The Phenomenal Judgment Approach. In: The Journal of Mind and Behavior, 2014, Vol. 35, No. 1/2, pp. 51-70.

ATWOOD, Margaret: Handmaid's Tale. New York: O. W. Toad Ltd. 1986. 311 p.

BALL, Derek: There Are No Phenomenal Concepts. In: Mind, 2009, Vol. 118. No. 472, pp. 935-962.

BALOG, Katalin: Phenomenal Concepts. In: The Oxford Handbook of Philosophy of Mind. Ed. B. P. McLaughlin - A. Beckermann - S. Walter. Oxford, UK: Clarendon Press 2009, pp. 292-312.

BERMUDEZ, Jose: The Distinction Between Conceptual and Non-Conceptual Content. In: The Oxford Handbook of Philosophy of Mind. Ed. B. P. McLaughlin - A. Beckermann S. Walter. Oxford, UK: Clarendon Press 2009, pp. 457-473. 
BERTA, Luca: Qualia from the Point of View of Language. In: The Journal of Mind and Behavior, 2011, Vol. 32, No. 5, pp. 181-208.

BUCCI, Wilma et al.: Connecting Emotions and Words: The Referential Process. In: Phenomenology and the Cognitive Sciences, 2016, No. 15, pp. 359-383.

CAMP, Elizabeth: Two Varieties of Literary Imagination: Metaphor, Fiction, and Thought Experiment. In: Midwest Studies in Philosophy, 2009, No. 23, pp. 107-130.

CARRUTHERS, Peter: Language, Thought, and Consciousness. Cambridge, UK: Cambridge University Press 1996. 291 p.

CHALMERS, David: The Conscious Mind: In Search of a Fundamental Theory. Oxford: Oxford University Press 1996. 414 p.

DEACON, Terrence: The Symbolic Species: The Co- Evolution of Language and the Human Brain. New York, NY: The Penguin Press 1997. 527 p.

DENNETT, Daniel: Consciousness Explained. New York, NY: Penguin Books 1991. 511 p.

DENNETT, Daniel: Quining Qualia. In: Readings in Philosophy and Cognitive Science. Ed. A. Goldman. Cambridge, MA: MIT Press 1993, pp. 381-414.

DENNETT, Daniel: Sweet Dreams. Philosophical Obstacles to the Science of Consciousness. Cambridge, MA: The MIT Press 2005. 216 p.

FREEMAN, Margaret: Feeling, Form, and Meaning in the Creation of Poetic Iconicity. In: Cognitive poetics: A Critical Introduction. Ed. G. Brone - J. Vandaele. Berlin: Mouton de Gruyter 2009, pp. 169-196.

FREGE, Gottlob: The Thought: A Logical Inquiry. In: Mind, 1956, Vol. 65, No. 259, pp. 289-311.

HART, Elizabeth: The Epistemology of Cognitive Literary Studies. In: Philosophy and Literature, 2001, Vol. 25 No. 2, pp. 314-334.

JAKAB, Zoltán: Ineffability of Qualia: A Straightforward Naturalistic Explanation. In:

Consciousness and Cognition, 2000, Vol. 9, No. 3, pp. 329-351.

KOENIG, John: The Dictionary of Obscure Sorrows. New York, NY: Simon and Schuster 2021. $288 \mathrm{p}$.

LANGER, Susanne K.: Philosophy in a New Key. New York, NY: Penguin Books 1942. $248 \mathrm{p}$.

LEWIS, David: Mind and the World Order: Outline of a Theory of Knowledge. New York, NY: Dover Publications 1991. 446 p.

LOAR, Brian: Phenomenal States. In: Philosophical Perspectives 4: Action Theory and Philosophy of Mind. Ed. J. Tomberlin. Atascadero: Ridgeview 1990, pp. 81-108.

LOVE, Nigel: Are Languages Digital Codes? In: Language Sciences, 2007, No. 29, pp. 690-709.

MÁRTON, Miklos - TÖZSÉR, János: Physicalism and the Privacy of Conscious Experience. In: Journal of Cognition and Neuroethics, 2016, Vol. 4, No. 1, pp. 73-88.

MUSACCHIO, Jose M.: The Ineffability of Qualia and the Word-Anchoring Problem. In: Language Sciences, 2005, Vol. 27, No. 4, pp. 403-435.

NABOKOV, Vladimir: Lolita. Revised and Updated. New York, NY: Vintage Books 1991. $331 \mathrm{p}$.

NAGEL, Thomas: What Is It Like to Be a Bat? In: Philosophical Review, 1974, Vol. 8, No. 4, pp. 435-450. 
PAPINEAU, David: Phenomenal Concepts and Perceptual Concepts. In Phenomenal Concepts and Phenomenal Knowledge. New Essays on Consciousness and Physicalism. Ed. T. Alter \& S. Walter. Oxford, UK: Oxford University Press 2007, pp. 111-144.

PERRY, John: Knowledge, Possibility, and Consciousness. Cambridge, MA: The MIT Press 2001. $221 \mathrm{p}$.

PILKINGTON, Adrian: Non-Lexicalised Concepts and Degrees of Effability: Poetic Thoughts and the Attraction of What Is Not in the Dictionary. In: Belgian Journal of Linguistics, 2001, Vol. 15, No. 1, pp. 1-10.

POE, Edgar Allan: The Fall of the House of Usher and Other Writings. London, UK: Penguin Book 2003. 560 p.

RAIBLE, Wolfgang: Language and consciousness. In: Exploring Consciousness. Humanities, Natural Science, Religion. Proceedings of the International Symposium. Milano: Fondazione Carlo Erba 2003, pp. 17-34.

SEARLE, John: Speech Acts. Cambridge: Cambridge University Press 1969. 203 p.

SHAKESPEARE, William: King Lear. Cambridge: Cambridge University Press 2009. $256 \mathrm{p}$.

SUNDSTRÖM, Petra: Phenomenal Concepts. In: Philosophy Compass, 2001, Vol. 6. No. 4, pp. 267-81.

TARTT, Donna: The Goldfinch. New York, NY: Back Bay Books 2014. 962 p.

TYE, Michael: A Theory of Phenomenal Concepts. In: Minds and Persons: Royal Institute of Philosophy Supplement. Ed. A. O'Hear. Cambridge, UK: Cambridge University Press 2003, pp. 90-105.

TYE, Michael: Qualia. In: The Stanford Encyclopedia of Philosophy. Ed. E. N. Zalta. Summer 2018 Edition. Available at: https://plato.stanford.edu/archives/sum2018/entries/qualia/. [cit. 14.12.2020].

WATZLAWICK, Paul et al.: The Pragmatics of Communication: A Study of Interactional Patterns, Pathologies, and Paradoxes. New York NY: WW Norton and Co. 2014. 304 p.

WITTGENSTEIN, Ludwig: Philosophical Investigations. Hoboken, NJ: Blackwell Publishing 2001. 592 p.

ZENTNER, Marcel: A Language for Musical Qualia. In: Empirical Musicology Review, 2012, Vol. 7, No. 1/2, pp. 80-83.

ZLATEV, Jordan: The Dialectics of Consciousness and Language. In: Journal of Consciousness Studies, 2008, Vol. 15, No. 6, pp. 5-14.

\section{Resumé}

\section{„POVEDZ MI, AKÝ JE TO POCIT“: O JAZYKOVOM STVÁRNENÍ FENOMENÁLNA}

K častým pozorovaniam patrí jednak to, že niektoré naše myšlienkové obsahy - konkrétne tie, ktoré súvisia so zmyslovou skúsenost'ou, - sa t'ažko vyjadrujú, a tiež to, že aj v prípade uskutočnenej komunikácie o nich pocit’ujeme istý rozpor medzi zamýšl’aným a vysloveným. Pre zástancov pozitivizmu táto nevyjadritel'nost' nepredstavuje žiadnu záhadu, pretože ju po- 
važujú výlučne za znak nedostatočnej jazykovej kompetencie; iní naopak tento fakt vnímajú ako závažnejší problém a tvrdia, že vzniká v dôsledku nesúladu medzi fungovaním zmyslového vnímania a l’udského jazyka. Len zriedka sa však systematicky skúma konkrétne jazykové stvárnenie spomenutého rozporu, a teda špecifický mechanizmus, pomocou ktorého sa prekonáva nevyjadritel'nost' inak t'ažko verbalizovatel'ných obsahov zmyslového vnímania. Príspevok je pokusom o opätovné nastolenie problému, aký predstavuje relatívna nevyjadritel'nost' fenomenálnych myšlienkových obsahov, takzvaných kválií, a teda nevyjadritel'nost' v pravom zmysle privátneho, nepropozičného poznania, ktoré získavame prostredníctvom zmyslového vnímania. V príspevku najprv vo všeobecnosti načrtávam nevyjadritel'nost' zmyslových vnemov a potom predkladám krátku diskusiu o subjektívnosti kválií a s nimi súvisiacich jazykových problémoch. Následne navrhujem považovat' kváliá za nevyjadritel'né len $\mathrm{v}$ užšom zmysle - pokial' je potrebné pomenovat' ich priamo. Na základe dokladov z literárneho diskurzu, ktorý je primárnou doménou fenomenálnych mentálnych obsahov organizovaných ako koherentný text, tvrdím, že našu fenomenologickú skúsenost' typicky verbalizujeme prostredníctvom relačných opisov, ktoré fungujú zhruba ako metafory vyjadrujúce podobnost' medzi rozdielnymi vecami. Takéto diskurzívne jednotky (odkazujúce na kváliá rečníka a vol'ne sa opierajúce o analytický pojem „fenomenálnych súdov“) nazývam fenomémy. V závere príspevku v krátkosti uvažujem o fenomémach ako naratívnej technike, vd’aka ktorej si čitatelia vytvárajú užší vzt’ah s literárnymi textami, a prezentujem „čítanie myšlienok“ ako východisko interpretačného uchopenia. Prezentovaný výskum podnietila relatívne malá pozornost', aká sa napriek očividnému jazykovému rozmeru tejto problematiky venuje vzt'ahu medzi jazykom a kváliami (výnimkou sú práce Bertu, 2011; Carruthersa, 1996; Zlateva, 2008). V príspevku si v tomto zmysle kladiem za ciel' navrhnút' predbežný model na diskusiu o nevyjadritel'nosti fenomenálnych myšlienkových obsahov v kontexte kognitívnej štylistiky a diskurznej analýzy. 